\title{
IMPLEMENTASI KEPMEN ESDM No. 1827 K/30/MEM/2018 TERKAIT KEDALAMAN AKHIR PENAMBANGAN LEBIH DARI 45 METER DALAM PERSPEKTIF ASPEK TEKNIS PERTAMBANGAN DAN ASPEK KONSERVASI MINERAL DAN BATUBARA
}

\author{
IMPLEMENTATION OF THE DECREE OF THE MINISTER OF ENERGY AND MINERAL \\ RESOURCES No. 1827 K/3O/MEM/2018 RELATED TO THE FINAL DEPTH OF MINING MORE \\ THAN 45 METERS IN THE PERSPECTIVE OF TECHNICAL ASPECTS OF MINING AND \\ ASPECT OF MINERAL AND COAL CONSERVATION
}

\author{
Yoan Desianda \\ Inspektur Tambang Ahli Muda, Direktorat Teknik dan Lingkungan Mineral dan Batubara, Kementerian ESDM, \\ Provinsi Sumatera Selatan \\ Corresponding Author E-mail: yoan.desianda@esdm.go.id
}

\begin{abstract}
Guidelines for the Implementation of Good Mining Engineering Rules, in Appendix II concerning Guidelines for Mining Technical Management, and looking more deeply on page 94 letter (x) states that "if the final mining depth is more than 45 (forty five) meters, two accesses are available. for entry and exit. Therefore, on this occasion the author will try to put it in an article. The research used is descriptive qualitative. Samples were taken from coal mining business activities and calculations were carried out at the PT XYZ mine using the open pit mining method in South Sumatra Province. Data analysis was carried out based on several modeling access roads that can be planned and optimization of coal recovery that can be achieved from these road access models. Data is presented in the form of pictures, tables, narratives and maps. The current mining/production road with one access road in and out (two directions) with a width of 25 meters, total coal reserves is estimated at 12,984,664 tons. Modeling with two separate access roads between OB Hauling and Coal Hauling with a road width of $20 \mathrm{~m}$, the amount of coal reserves extracted is reduced to $8,841,657$ tons with a maximum depth of $140 \mathrm{~m}$ or based on conservation aspects, the reserves that can be extracted will be reduced by 4,143,007 tons . Based on considerations of technical aspects and aspects of mineral and coal conservation, so that reserves can be taken optimally, the choice is made by making the existing road with a width of $25 \mathrm{~m}$, the road will be modified by dividing the width of the road into 2 (two) sections with separator, which is $9 \mathrm{~m}$ for coal transportation equipment and $13 \mathrm{~m}$ for $\mathrm{OB}$ material transportation means, so that the estimated coal reserves of 12,984,664 tons can be taken entirely with a maximum depth of $200 \mathrm{~m}$

Keywords: Pit, Mine Road, Technical Aspect, Conservation, Optimization, Reserve
\end{abstract}

\begin{abstract}
Abstrak: Pedoman Pelaksanaan Kaidah Teknik Pertambangan Yang Baik, pada Lampiran II tentang Pedoman Pengelolaan Teknis Pertambangan, dan menilik lebih dalam lagi pada halaman 94 huruf (x) menyatakan bahwa dalam hal kedalaman akhir penambangan lebih dari 45 (empat puluh lima) meter maka tersedia dua akses untuk jalan masuk dan jalan keluar. Oleh sebab itu, penulis dalam kesempatan ini akan mencoba menuangkan dalam sebuah tulisan. Penelitian yang digunakan bersifat deskriptif kualitatif. Sample diambil pada kegiatan usaha pertambangan batubara dan perhitungan yang dilakukan pada tambang PT XYZ dengan menggunakan metode tambang terbuka di Provinsi Sumatera Selatan. Analisis data dilakukan berdasarkan beberapa pemodelan akses jalan yang dapat direncanakan dan optimalisasi perolehan batubara yang dapat dicapai dari beberapa pemodelan akses jalan tersebut. Data disajikan dalam bentuk gambar, tabel, narasi dan peta. Jalan tambang/produksi saat ini dengan satu akses jalan masuk dan keluar (dua arah) dengan lebar 25 meter, jumlah cadangan batubara terkira 12.984.664 ton. Pemodelan dengan dua akses jalan terpisah antara OB Hauling dan Coal Hauling dengan lebar jalan 20 m, maka jumlah cadangan batubara terambil berkurang menjadi 8.841 .657 ton dengan kedalaman maksimal $140 \mathrm{~m}$ atau berdasarkan aspek Konservasi maka cadangan yang bisa diambil akan berkurang sebanyak 4.143.007 ton. Dengan berdasarkan pertimbangan aspek teknis dan aspek konservasi mineral dan batubara, agar cadangan bisa terambil secara optimal, maka pilihan diambil dengan membuat jalan yang sudah ada saat ini dengan lebar $25 \mathrm{~m}$, jalan tersebut akan dimodifikasi dengan membagi lebar jalan menjadi 2 (dua) bagian dengan separator, yaitu $9 \mathrm{~m}$ untuk alat angkut batubara dan $13 \mathrm{~m}$ untuk alat angkut material OB, sehingga cadangan batubara terkira 12.984 .664 ton dapat terambil seluruhnya dengan kedalaman maksimal $200 \mathrm{~m}$.
\end{abstract}

Kata kunci : Pit, Jalan Tambang, Aspek Teknis, Konservasi, Optimalisasi, Cadangan. 


\section{PENDAHULUAN}

\subsection{Latar Belakang}

Mineral dan batubara yang terkandung dalam wilayah hukum pertambangan Indonesia merupakan kekayaan alam tak terbarukan sebagai bentuk karunia Tuhan Yang Maha Esa yang mempunyai peranan penting dalam memenuhi hajat hidup orang banyak, karena itu pengelolaannya harus dikuasai oleh negara untuk memberi nilai tambah secara nyata bagi perekonomian nasional dalam usaha mencapai kemakmuran dan kesejahteraan rakyat secara berkeadilan.

Tahap selanjutnya, kegiatan usaha pertambangan mineral dan batubara mempunyai peranan penting dalam memberikan nilai tambah secara nyata kepada pertumbuhan ekonomi nasional dan pembangunan dearah secara berkelanjutan. Sehingga berdasarkan pertimbangan perkembangan nasional maupun internasional untuk dapat mengelola dan mengusahakan potensi mineral dan batubara secara mandiri, andal, transparan, berdaya saing, efisien, dan berwawasan lingkungan, guna menjamin pembangunan nasional secara berkelanjutan, maka lahirlah Undang-undang Nomor 4 Tahun 2009 tentang Pertambangan Mineral dan Batubara yang diundangkan pada tanggal 12 Januari 2009 sebagai pengganti Undangundang Nomor 11 Tahun 1967 tentang Ketentuan-ketentuan Pokok Pertambangan, sebagaimana telah diubah dengan Undangundang Nomor 3 Tahun 2020 tentang Perubahan Atas Undang-undang Nomor 4 Tahun 2009 tentang Pertambangan Mineral dan Batubara yang diundangkan pada tanggal 10 Juni 2020. Ketentuan lebih lanjut mengenai pelaksanaan undang undang diatur dalam beberapa aturan turunan, seperti : peraturan pemerintah, peraturan menteri, keputusan menteri dan sebagainya.

Pada Keputusan Menteri Energi dan Sumber Daya Mineral (Kepmen ESDM) Nomor 1827K/30/MEM/2018 tanggal 7 Mei 2018 tentang Pedoman Pelaksanaan Kaidah Teknik Pertambangan Yang Baik, merupakan ketentuan lebih lanjut dari Peraturan Menteri ESDM Nomor 26 Tahun 2018 tentang
Pelaksanaan Kaidah Pertambangan yang Baik dan Pengawasan Pertambangan Mineral dan Batubara, sebagai pengganti dari Keputusan Menteri Pertambangan dan Energi Nomor 555.K/26/M.PE/1995 tentang Keselamatan dan Kesehatan Kerja Umum tanggal 22 Mei 1995.

\subsection{Batasan Masalah}

Merujuk pada Kepmen ESDM Nomor 1827K/30/MEM/2018 tentang Pedoman Pelaksanaan Kaidah Teknik Pertambangan Yang Baik, pada Lampiran II tentang Pedoman Pengelolaan Teknis Pertambangan, dan menilik lebih dalam lagi pada halaman 94 huruf (x) menyatakan bahwa "dalam hal kedalaman akhir penambangan lebih dari 45 (empat puluh lima) meter, maka tersedia dua akses untuk jalan masuk dan jalan keluar".

Hal ini perlu menjadi perhatian dalam mengimplementasikan ketentuan tersebut, karena akan menjadi sangat penting apabila dilihat dari sudut pandang teknik pertambangan dan optimalisasi (aspek konservasi) kegiatan usaha pertambangan mineral dan batubara. Pada kesempatan ini diambil sampel hasil inspeksi atas perhitungan yang dilakukan pada tambang PT XYZ komoditas batubara dengan menggunakan metode tambang terbuka di Provinsi Sumatera Selatan.

\subsection{Tujuan}

Tujuan dari penulisan ini antara lain:

1. Untuk memberikan gambaran terkait implementasi tersedianya dua akses untuk jalan masuk dan jalan keluar dari perspektif teknik pertambangan dan konservasi mineral dan batubara.

2. ntuk mengetahui beberapa model dua akses untuk jalan masuk dan jalan keluar yang dapat diterapkan dari aspek teknik pertambangan.

3. Mengetahui tingkat efektivitas keterambilan cadangan apabila ditinjau dari aspek konservasi mineral dan batubara.

\section{METODOLOGI PENELITIAN}

\subsection{Waktu dan Tempat}


Penelitian dilaksanakan pada bulan Maret 2021 pada Izin Usaha Pertambangan Operasi Produksi (IUP OP) PT XYZ komoditas batubara menggunakan metode tambang terbuka di Provinsi Sumatera Selatan.

\subsection{Alat dan Bahan}

a. Alat

Alat yang digunakan dalam melakukan penelitian ini bekerja sama dengan hasil perhitungan teknis PT XYZ menggunakan pemrograman komputer Minescape.

b. Bahan

Bahan-bahan yang digunakan, seperti: dokumen studi kelayakan, dokumen kajian teknis, dokumen rencana kerja dan anggaran biaya, dan peraturan perundangan.

\subsection{Sifat dan Pendekatan Penelitian}

Tulisan ini menggunakan data dari dokumen kelayakan, kajian teknis, rencana kerja dan peraturan perundangan yang berlaku saat ini serta literatur ilmiah mengenai jalan tambang, pit, aspek teknis, aspek konservasi dan optimalisasi cadangan.

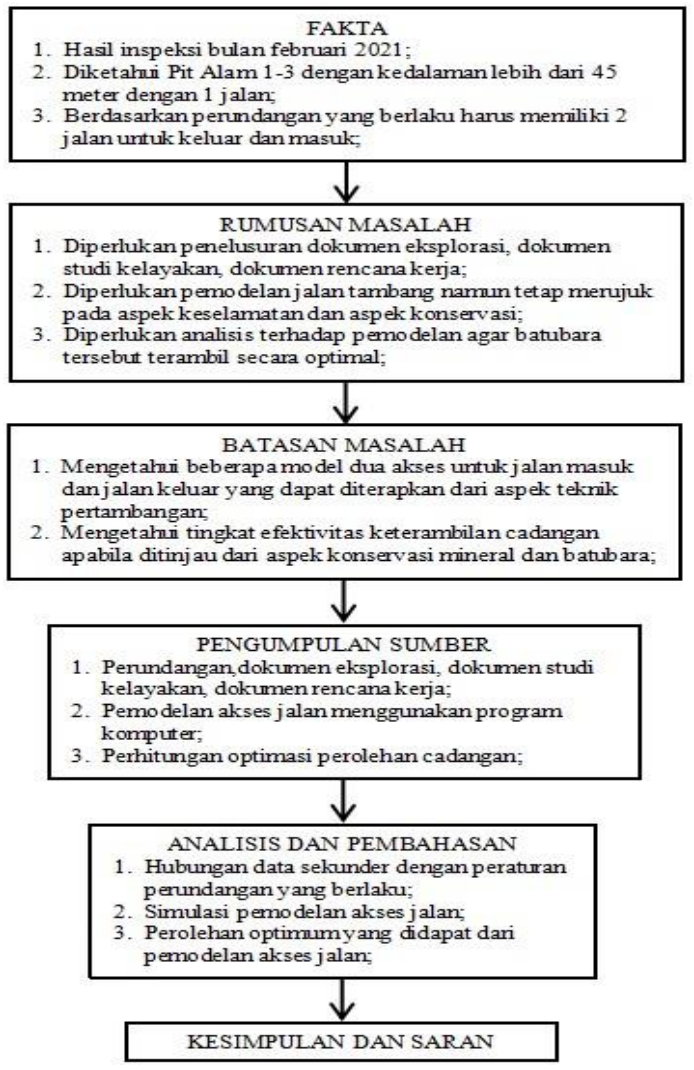

Gambar 2.1 Bagan Alir Penelitian
Penyelesaian dimodelkan melalui diagram alir untuk mencapai tujuan penulisan, dan ditambahkan analisis dan pembahasan untuk mendukung tujuan penulisan. Selanjutnya kesimpulan diambil dari analisis dan pembahasan yang dihubungkan dengan perundangan dan literatur dan teori untuk menjawab tujuan penelitian. Dari kesimpulan tersebut kemudian di kelola untuk mendapatkan saran. Untuk lebih jelas, dapat dilihat pada diagram alir pada Gambar 2.1.

\subsection{Populasi dan Sampel}

Pada kesempatan ini penulis mengambil sample IUP OP PT XYZ komoditas batubara atas perhitungan yang dilakukan dengan menggunakan metode tambang terbuka di Provinsi Sumatera Selatan.

\subsection{Prosedur Kerja}

Langkah-langkah kerja secara garis besar terdiri dari 3 (tiga) tahap, yaitu: inspeksi, pengolahan data, dan analisis data

a. Inspeksi, dilakukan dalam beberapa cara, yaitu: dengan melakukan penelusuran dokumen administrasi yang dimiliki berupa: dokumen laporan eksplorasi, dokumen studi kelayakan dan pelaksanaan kegiatan penambangan di lapangan.

1. Untuk dokumen laporan eksplorasi dilakukan dengan cara membaca data bor dan hasil perhitungan sumber daya dan cadangan perusahaan. Selanjutnya untuk dokumen studi kelayakan dilakukan dengan cara menentukan rencana penambangan pada pit dengan kedalaman > $45 \mathrm{~m}$;

2. Untuk pelaksanaan lapangan dengan melakukan peninjauan kondisi terkini dari Pit dengan kedalaman $>45 \mathrm{~m}$;

b. Pengolahan data, data diambil dari informasi dokumen dan kondisi lapangan yang menyatakan bahwa pit tersebut akan digali dengan kedalaman $>45 \mathrm{~m}$, data yang didapat diolah menggunakan pemrograman komputer Minescape.

c. Analisis data, menggunakan pemrograman komputer Minescape, dengan menghasilkan beberapa simulasi model 
jalan dan ketercapaian maksimum dari kedalaman yang dapat dicapai dengan beberapa pemodelan akses jalan, serta perolehan batubara yang optimal dari beberapa model akses jalan yang direncanakan.

\subsection{Analisis Data}

Analisis data dilakukan berdasarkan pemodelan akses jalan yang direncanakan dan optimalisasi perolehan batubara yang dapat dicapai dari pemodelan akses jalan tersebut.

\section{HASIL DAN PEMBAHASAN}

\subsection{Data Sekunder Lokasi Penelitian}

Batubara adalah endapan senyawa organik karbonan yang terbentuk secara alamiah dari sisa tumbuh-tumbuhan. Merujuk kepada Standar Nasional Indonesia, terkait sumberdaya dan cadangan batubara berpedoman pada (SNI 5015;2019) tentang Pedoman Pelaporan Sumberdaya dan Cadangan Batubara:

a. Sumberdaya batubara

Sumberdaya batubara adalah bagian dari batubara dalam bentuk dan kualitas tertentu serta mempunyai prospek beralasan yang memungkinkan untuk ditambang secara ekonomis. Sumberdaya batubara dibagi sesuai dengan tingkat kepercayaan geologi.

Perhitungan sumberdaya batubara menggunakan metode kemenerusan batubara yang telah dibuktikan dengan lubang bor dan dibentuk radius sesuai dengan jarak titik pengamatan menurut kondisi geologi (gambar 3.1) sehingga membentuk kategori Tereka, Terunjuk dan Terukur, dengan persamaan sebagai berikut:

$$
\mathrm{R}=\mathrm{L} \times \mathrm{t} \times \mathrm{ID}
$$

Dimana:

$\mathrm{R}=$ jumlah sumberdaya (ton)

$\mathrm{L}=$ daerah pengaruh dari titik informasi $\left(\mathrm{m}^{2}\right)$

$\mathrm{T}=$ ketebalan batubara (true thickness) (m)

$\mathrm{ID}=$ densitas batubara $\left(\right.$ ton $\left./ \mathrm{m}^{3}\right)$

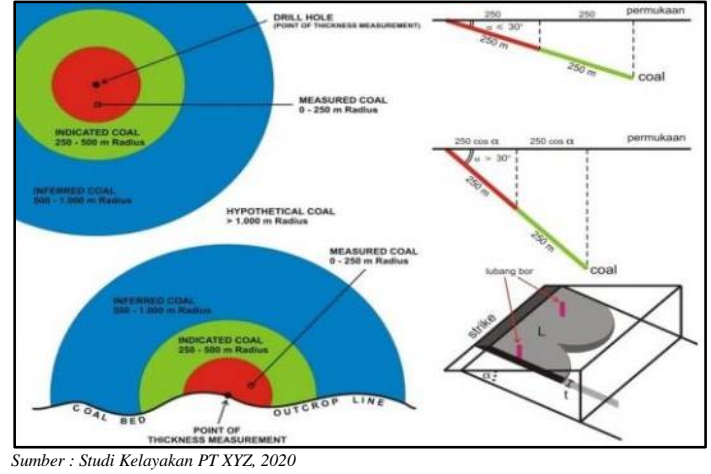

Gambar 3.1 Model Perhitungan Sumberdaya

Dari perhitungan tersebut, didapat penampang melintang secara 2-Dimensi dari deposit batubara PT XYZ seperti gambar 3.2.

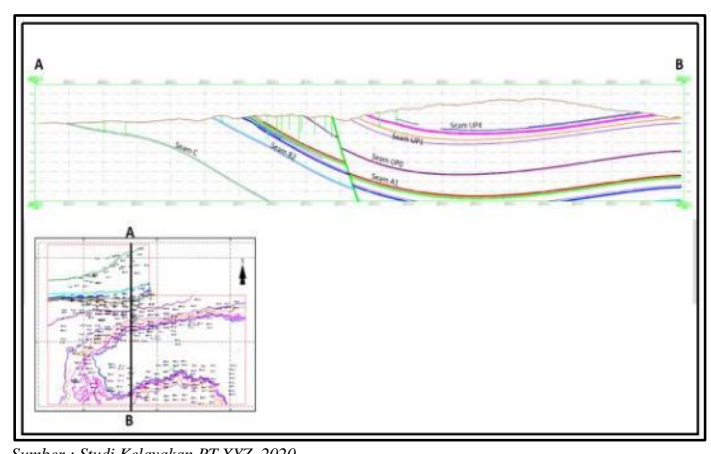

Gambar 3.2 Penampang Melintang Seam

Didapat total estimasi sumberdaya batubara yang telah divalidasi oleh Competent Person Indonesia sebesar 80.908.052 ton, terdiri dari 24.489.067 ton sumberdaya tereka, 41.426 .311 ton sumberdaya terunjuk, dan 14.992.674 ton sumberdaya terukur sebagaimana tabel 3.1 .

Tabel 3.1 Sumberdaya Batubara PT XYZ

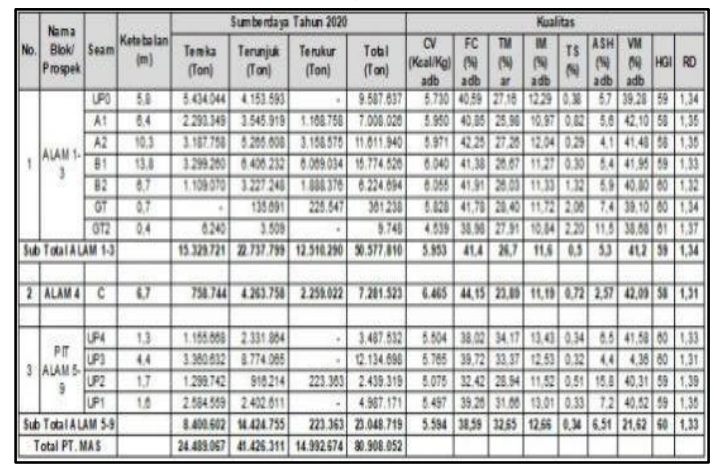

Sumber : Studi Kelayakan PT XYZ 2020 
b. Cadangan batubara

Cadangan batubara adalah bagian dari sumberdaya batubara terunjuk dan/atau terukur yang dapat ditambang secara ekonomis. Dalam proses estimasi cadangan batubara, studi yang tepat pada tingkat minimum pra-studi kelayakan harus sudah dilakukan dengan mempertimbangkan semua faktor pengubah (modifying factors) yang relevan meliputi teknis penambangan, pengolahan, sarana dan prasarana, ekonomi, pemasaran, legal, sosial, lingkungan, dan peraturan yang berlaku. Studi tersebut harus bisa mendemonstrasikan bahwa cadangan batubara tersebut secara teknis dapat ditambang dan secara ekonomi menguntungkan.

Perhitungan estimasi cadangan batubara mempertimbangkan rencana kedalaman, jumlah estimasi dilusi dan losses, kerapatan data, kualitas batubara, dan perangkat lunak yang digunakan untuk menghitung cadangan adalah Xpac.

Perhitungan cadangan batubara berpedoman pada (SNI 5015;2019), dibagi menjadi Terkira, Terbukti, Tidak tertambang, dan Marginal. Berdasarkan tingkat keyakinannya, maka cadangan batubara dibagi menjadi cadangan terkira dan cadangan terbukti.

Didapat total estimasi cadangan batubara yang telah divalidasi oleh Competent Person Indonesia sebesar 26.508.325 ton, terdiri dari 17.283.066 ton cadangan terkira, dan 9.225.258 ton cadangan terbukti sebagaimana tabel 3.2.

Tabel 3.2 Cadangan Batubara PT XYZ

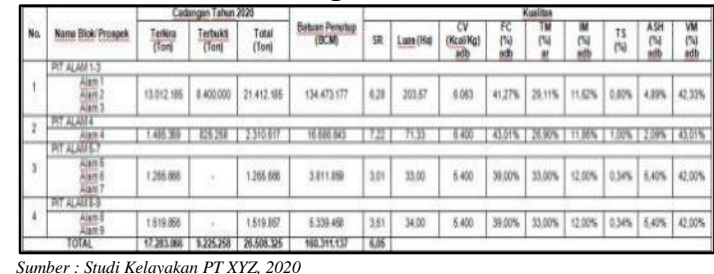

Cadangan yang telah tertambang sejak tahun 2009 sampai dengan tahun 2019 sebanyak 14.390.032 ton. Dengan sudah tervalidasinya cadangan batubara oleh Competent Person Indonesia sebagaimana tabel 3.2 di atas, maka luas bukaan pit penambangan sampai dengan tahun 2030 nanti sebesar 103,27 Ha., dengan elevasi terendah pit penambangan adalah RL-130.

c. Sistem/metoda penambangan

Dasar dalam penentuan metode penambangan adalah berdasarkan pada keuntungan terbesar yang dapat diperoleh, pemilihan metode penambangan juga berdasarkan pada perolehan tambang (mining recovery) yang terbaik. Faktorfaktor yang mempengaruhi pemilihan sistem penambangan batubara adalah karakteristik spesial dari endapan, kondisi geologi dan hidrogeologi, sifat-sifat geoteknik, konsiderasi ekonomi, teknologi dan lingkungan.

Berdasarkan faktor-faktor di atas, maka sistem penambangan yang paling sesuai untuk diterapkan pada IUP OP PT XYZ adalah sistem tambang terbuka (open pit mining). Open pit adalah salah satu metode dalam tambang terbuka yang digunakan pada endapan batubara yang relatif datar dengan permukaan tanah, dan memiliki satu atau lebih lapisan batuan penutup di atasnya. Ilustrasi skema penambangan metode open pit mining dapat dilihat pada (Gambar 3.3).

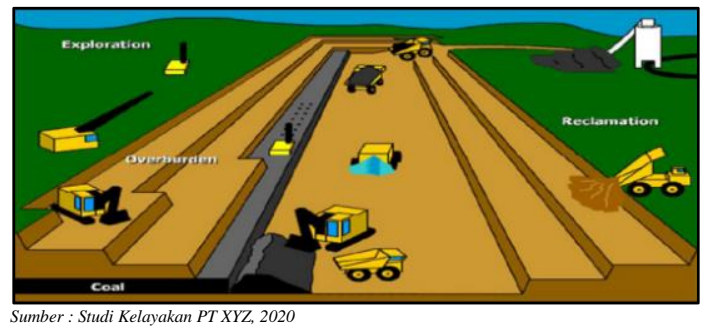

Gambar 3.3 Skema Penambangan Open Pit Mining

Berdasarkan hasil analisis kajian geoteknik yang dilakukan, maka rekomendasi lereng tunggal dan keseluruhan untuk masing-masing Pit dapat digambarkan sebagaimana Tabel 3.3. 
Tabel 3.3 Rekomendasi Single Slope dan Overall

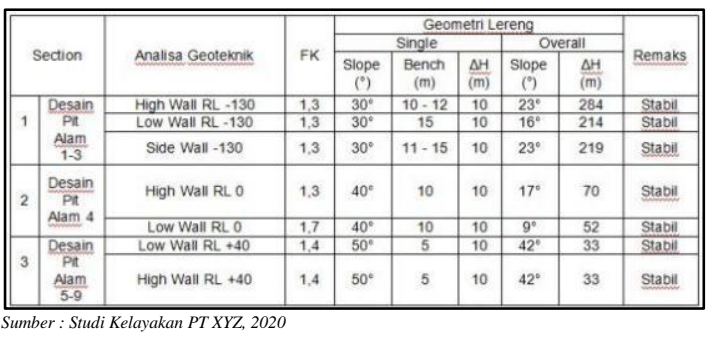

Dari rekomendasi geoteknik pada tabel 3.3, maka untuk Pit Alam 1-3 PT XYZ akan membentuk elevasi terbawah pit di level -130 mdpl, sehingga kedalaman pit Alam 1-3 dari rona awal akan mencapai rata-rata 200 meter.

Berdasarkan data tersebut, berdasarkan Kepmen ESDM Nomor 1827K/30/MEM/2018 tentang Pedoman Pelaksanaan Kaidah Teknik Pertambangan yang Baik pada halaman 94 huruf (x) dinyatakan bahwa "dalam hal kedalaman akhir penambangan lebih dari 45 (empat puluh lima) meter maka tersedia dua akses untuk jalan masuk dan jalan keluar", sehingga diperlukan suatu kajian teknis.

d. Peralatan Operasi Penambangan dan Jalan Pertambangan

Peralatan operasi penambangan yang akan dibahas dalam tulisan ini adalah alat yang digunakan dalam mendukung kegiatan penambangan PT XYZ. Peralatan yang digunakan terdiri dari peralatan utama (alat gali/muat, alat angkut) dan peralatan pendukung, sebagaimana Tabel 3.4 sampai dengan Tabel 3.6 berikut:

Tabel 3.3 Peralatan Utama (Alat Gali/Muat)

\begin{tabular}{||c|c|c|c|c|c||}
\hline No & Model Unit & MerkUnit & Type Unit & $\begin{array}{c}\text { Bucket } \\
\text { Capacity } \\
\left(\mathrm{m}^{3}\right)\end{array}$ & $\begin{array}{c}\text { Lebar } \\
\text { Unit } \\
(\mathrm{m})\end{array}$ \\
\hline \hline 1 & EXCAVATOR & HITACHI & ZX870H & 3.60 & 4.10 \\
\hline 2 & EXCAVATOR & HITACHI & ZX470LCH & 2.40 & 3.49 \\
\hline 3 & EXCAVATOR & HITACHI & ZX350H & 1.38 & 3.19 \\
\hline 4 & EXCAVATOR & KOMATSU & PC400-7 & 2.40 & 3.34 \\
\hline 5 & EXCAVATOR & KOMATSU & PC200-7 & 0.93 & 3.00 \\
\hline 6 & EXCAVATOR & HITACHI & ZX200-5G & 0.91 & 2.80 \\
\hline 7 & EXCAVATOR & HITACHI & ZX330 & 1.40 & 3.19 \\
\hline
\end{tabular}

Tabel 3.5 Peralatan Utama (Alat Angkut)

\begin{tabular}{|c|c|c|c|c|c||}
\hline No & $\begin{array}{c}\text { Model } \\
\text { Unit }\end{array}$ & Merk Unit & Type Unit & $\begin{array}{c}\text { Vessel } \\
\text { Capacity } \\
\text { Standar } \\
\text { BSS }\end{array}$ & $\begin{array}{c}\text { Lebar } \\
\text { Unit } \\
\text { (m) }\end{array}$ \\
\hline \hline 1 & ADT & CATERPILLAR & $740 \mathrm{~B}$ & $16 \mathrm{Bcm}$ & 3.77 \\
\hline 2 & CMT & LGMG & CMT-96 & $24 \mathrm{Bcm}$ & 3.67 \\
\hline 3 & DT & MERCEDES-BENZ & ACTROS 4043K & $12 \mathrm{Bcm}$ & 2.52 \\
\hline 4 & DT & BEIBEN & 2642 & $12 \mathrm{Bcm}$ & 2.50 \\
\hline 5 & DT & HINO & FMB20TI CH & 24 ton & 2,40 \\
\hline 6 & DT & HINO & ZY1E 700 & $30-32$ ton & 2.49 \\
\hline 7 & DT & DONGFENG & TLIFT 375 CH & 24 ton & 2,40 \\
\hline
\end{tabular}

Tabel 3.6 Peralatan Pendukung

\begin{tabular}{||c|c|c|c|c|}
\hline No & Model Unit & Merk Unit & Type Unit & $\begin{array}{c}\text { Lebar } \\
\text { Unit } \\
\text { (m) }\end{array}$ \\
\hline \hline 1 & BULLDOZER & KOMATSU & D375A-6R & 4.69 \\
\hline 2 & BULLDOZER & KOMATSU & D155A-6 & 4.13 \\
\hline 3 & BULLDOZER & KOMATSU & D85ESS-2 & 3.62 \\
\hline 4 & BULLDOZER & KOMATSU & D65P-12 & 3.97 \\
\hline 5 & BULLDOZER & CATERPILLAR & D10R & 3.16 \\
\hline 6 & BULLDOZER & CATERPILLAR & D9R & 2.93 \\
\hline 7 & MOTOR GRADER & KOMATSU & GD705A-5 & 2.80 \\
\hline 8 & MOTOR GRADER & KOMATSU & GDS25A-2 & 3.31 \\
\hline 9 & MOTOR GRADER & CATERPILLAR & $16 \mathrm{M}$ & 3.10 \\
\hline 10 & COMPACTOR & SAKAI & SV515D-E & 2.30 \\
\hline 11 & COMPACTOR & SAKAI & SV525D-E & \\
\hline 12 & DRILLNG & SANDVIC & D245S & \\
\hline 13 & LOWBOY & MERCEDES-BENZ & ACTROS 4054LBY & \\
Sumber : Data Teknis PT XYZ, 202I & & & \\
\hline \multicolumn{5}{|l}{} \\
\hline
\end{tabular}

Berdasarkan data tersebut, maka perusahaan harus menyediakan jalan pertambangan berdasarkan Kepmen ESDM Nomor 1827K/30/MEM/2018, dengan ketentuan:

1) Lebar jalan tambang/produksi mempertimbangkan alat angkut terbesar yang melintasi jalan tersebut paling kurang :

a) tiga setengah kali lebar alat angkut terbesar, untuk jalan tambang dua arah,

b) dua kali lebar alat angkut terbesar, untuk jalan tambang satu arah, dan

c) lebar jalan pada jembatan sesuai ketentuan.

2) Pada setiap jalan tambang/ produksi tersedia tanggul pengaman di sisi luar badan jalan dengan tinggi minimal 3/4 (tiga per empat) diameter roda kendaraan terbesar dan memperhitungkan potensi air limpasan dan/atau meterial lepas yang dapat masuk ke jalan; 
3) Dalam hal jalan tambang/ produksi menggunakan tipe box cut, tanggul dapat tersedia;

4) Dalam hal kondisi jalan tambang/ produksi menggunakan tipe box cut dan berpotensi material lepas, dilakukan penguatan lereng;

5) Sepanjang jalan tambang/ produksi memiliki sistem penyaliran yang mampu mengalirkan debit air larian tertinggi dan dipelihara baik;

6) Sepanjang permukaan badan jalan tambang/produksi dibentuk kemiringan melintang (cross slope) paling kurang 2\% (dua persen);

7) Kemiringan (grade) jalan tambang/produksi dibuat tidak boleh $>12 \%$ memperhitungkan: spesifikasi kemampuan alat, jenis material jalan, fuel ratio penggunaan bahan bakar;

8) Dalam hal kemiringan jalan tambang/produksi $>12 \%$, lakukan kajian teknis;

9) Lebar, radius tikungan, dan super elevasi pada setiap jalan pertambangan yang menikung mampu menahan gaya dari setiap jenis kendaraan yang melintas dengan batasan kecepatan yang telah ditentukan;

10) Jalan pertambangan dilakukan pemeliharaan dan perawatan sehingga tidak menghambat kegiatan pengangkutan;

11) Daya dukung jalan pertambangan lebih kuat dari kapasitas terbesar beban kendaraan dan muatan yang melintas pada beban statis dalam kurun waktu tertentu berdasarkan kajian teknis;

12) Pada setiap tikungan dan persimpangan jalan tambang/ produksi dipasang pemisah jalur (separator) dengan tinggi paling kurang setengah diameter roda kendaraan terbesar dan lebar bagian atas paling kurang sama dengan lebar roda kendaraan terbesar;

13) Sudut belokan pada pertigaan jalan tidak boleh kurang dari $70^{\circ}$;

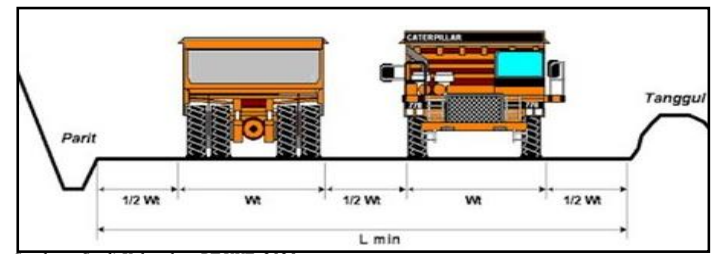

Gambar 3.4 Dimensi Jalan Tambang

Lebar jalan lurus menurut AASHTO:

$$
\mathrm{L}=\mathrm{n} \times \mathrm{Wt}+0,5 \times(\mathrm{n}+1) \times \mathrm{Wt}
$$

Lebar jalan berdasarkan Kepmen ESDM No. 1827 K/30/MEM/2018:

$$
\mathrm{L}=3 \frac{1}{2} \times \mathrm{Wt}
$$

$$
\begin{aligned}
& \text { Dimana : } \\
& \mathrm{L}=\text { lebar jalan angkut (m) } \\
& \mathrm{n}=\text { jumlah jalur } \\
& \mathrm{Wt}=\text { lebar alat angkut }(\mathrm{m})
\end{aligned}
$$

e. Pemodelan Akses Jalan dalam Studi Kelayakan

Dalam terminologi Kepmen ESDM Nomor 1827K/30/MEM/2018, jalan terdiri dari Jalan Pertambangan, Jalan Tambang/Produksi, Jalan Penunjang, dan Jalan Masuk.

1) Jalan pertambangan adalah jalan khusus yang yang diperuntukkan untuk kegiatan pertambangan dan berada diarea pertambangan atau area proyek yang terdiri atas jalan penunjang dan jalan tambang;

2) Jalan tambang/produksi adalah jalan yang terdapat pada area pertambangan dan/atau area proyek yang digunakan dan dilalui oleh alat pemindah tanah mekanis dan unit penunjang lain dalam kegiatan pengangkutan tanah penutup, bahan galian tambang, dan kegiatan penunjang pertambangan;

3) Jalan penunjang adalah jalan yang disediakan untuk jalan transportasi barang/orang dalam suatu area pertambangan dan/atau area proyek untuk mendukung operasi pertambangan atau penyediaan fasilitas tambang; 
4) Jalan masuk adalah jalan untuk memasuki area tambang permukaan dan tambang bawah tanah;

Saat ini berdasarkan dokumen studi kelayakan PT XYZ untuk Pit 1-3 yang telah mencapai kedalaman lebih dari $45 \mathrm{~m}$ pemodelan jalan tambang/produksi di design dengan satu akses jalan masuk dan keluar dengan lebar $25 \mathrm{~m}$, jumlah cadangan batubara terkira per Februari 2021 adalah 12.984.664 ton dan OB 113.848.687 BCM dengan SR 8,77:1. Luas bukaan pit 211,09 Ha. dan kedalaman $200 \mathrm{~m}$. Dengan lebar unit terbesar yang dipakai LGMG CMT 96 sebesar 3,67 m, maka diperlukan lebar jalan $3,5 \mathrm{x}$ unit terbesar, yaitu $12,8 \mathrm{~m}$. berdasarkan alat angkut terlebar $(3,77 \mathrm{~m})$ maka lebar jalan 13,2m.

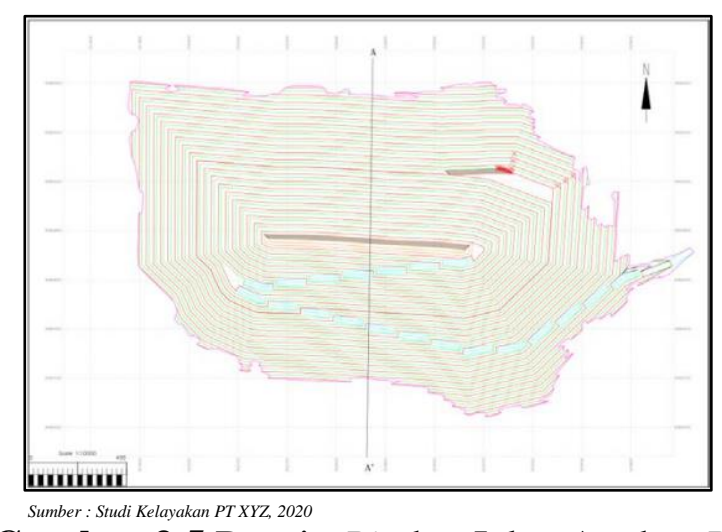

Gambar 3.5 Desain Pit dan Jalan Angkut Pit Alam 1-3 dengan 1 Akses Jalan

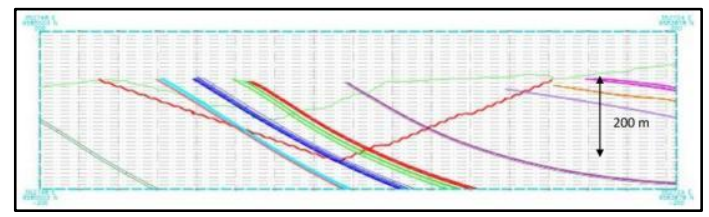

Sumber: Studi Kelayakan PT XYZ, 2020

Gambar 3.6 Cross Section Pit Alam 1-3 dengan 1 Akses Jalan

\subsection{Simulasi Pemodelan Akses Jalan}

Desain dua akses jalan masuk dan keluar, maka akses dibentuk di low wall dan high wall dimana akses highwall untuk akses hauling OB dan akses low wall untuk akses coal getting dengan lebar jalan masing-masing $20 \mathrm{~m}$.

Design dua akses jalan ini jumlah cadangan batubara berkurang menjadi 8.841.657 ton dan OB 61.631.882 bcm dengan SR 6,97. Kedalaman tambang maksimal sampai level -90 atau $140 \mathrm{~m}$ dari permukaan rona awal, lebih dari itu sudah tidak bisa dilakukan karena ujung jalan paling bawah sudah bertemu di bottom pit.

Berdasarkan aspek teknis pertambangan mineral dan batubara, maka dengan ketinggaian single slope $10 \mathrm{~m}$ dan sudut kemiringan lereng Pit Alam 1-3 HW RL-150, LW RL-150, dan HW RL-127 dan sebesar $45^{\circ}$, LW-127 sebesar $40^{\circ}$, LW RL-120 sebesar $30^{\circ}$, Pit 1-3 SW Timur dan Barat RL120 sebesar $40^{\circ}$ dan lereng masih termasuk dalam kategori aman dengan nilai safety factor sebesar 1,2.

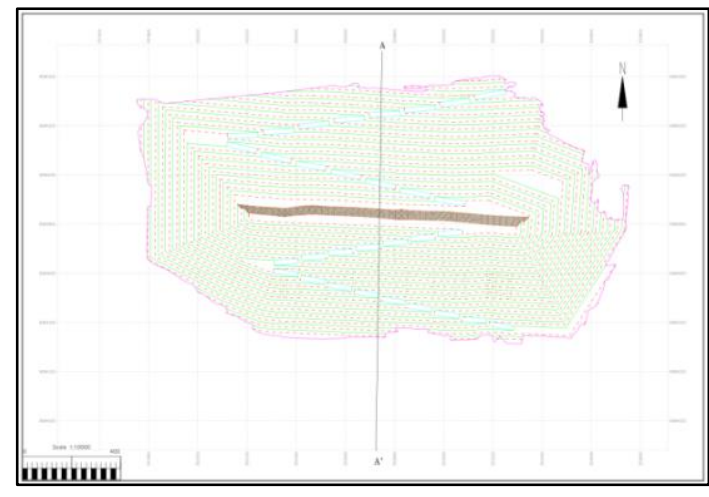

Gambar 3.7 Desain Pit dan Jalan Angkut Pit Alam 1-3 dengan 2 Akses Jalan

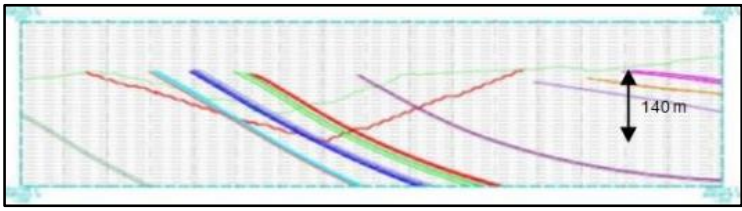

Sumber : Kajian Teknis PT XYZ, 202/

Gambar 3.8 Cross Section Pit Alam 1-3 dengan 2 Akses Jalan

Namun, merujuk pada aspek Konservasi, maka cadangan yang bisa diambil akan berkurang sebanyak 4.143.007 ton, ini tidak optimal dalam good mining practice, dan akan berakibat terpengaruhnya finansial perusahaan yang juga akan berkurang. 


\subsection{Perolehan Optimum yang Didapat dari Pemodelan Akses Jalan}

Dengan berdasarkan pertimbangan aspek teknis dan aspek konservasi mineral dan batubara, agar cadangan bisa terambil secara optimal. Untuk mengikuti rekomendasi dari kajian geotek dengan ketinggaian single slope $10 \mathrm{~m}$ dan sudut kemiringan lereng Pit Alam 13 HW RL-130, LW RL-130, dan HW RL-130 dan sebesar $30^{\circ}$ (single) dan $23^{\circ}$ (overall) dengan $(\mathrm{H}=284 \mathrm{~m}), \mathrm{LW}-130$ sebesar $30^{\circ}$ (single) dan $16^{\circ}$ (overall) dengan $(\mathrm{H}=214 \mathrm{~m})$, Pit 1-3 SW Timur dan Barat RL-130 sebesar $30^{\circ}$ dengan $(\mathrm{H}=219 \mathrm{~m})$ dan lereng dalam kategori aman dengan nilai safety factor sebesar 1,3. Sehingga pilihan diambil dengan membuat jalan yang sudah ada saat ini dengan lebar $25 \mathrm{~m}$, dengan membagi menjadi 2 (dua) bagian, yaitu $9 \mathrm{~m}$ untuk alat angkut komoditas batubara dan $13 \mathrm{~m}$ untuk alat angkut material OB dengan separator untuk membagi dua jalan tersebut seperti pada tabel 3.7.

Tabel 3.7 Lebar Jalan

\begin{tabular}{|c|l|r|r|r|}
\hline No. & \multicolumn{1}{|c|}{ Material } & \multicolumn{1}{c|}{$\begin{array}{c}\text { Lebar Unit } \\
(\mathbf{m})\end{array}$} & $\begin{array}{c}\text { Kebutuhan } \\
(\mathbf{m})\end{array}$ & \multicolumn{1}{c|}{$\begin{array}{c}\text { Pembulatan } \\
(\mathbf{m})\end{array}$} \\
\hline 1 & Overburden & 3.67 & 12.845 & 13.00 \\
\hline 2 & Coal & 2.4 & 8.4 & 9.00 \\
\hline \hline
\end{tabular}

Sebagaimana dapat diilustrasikan pada gambar 3.9 .

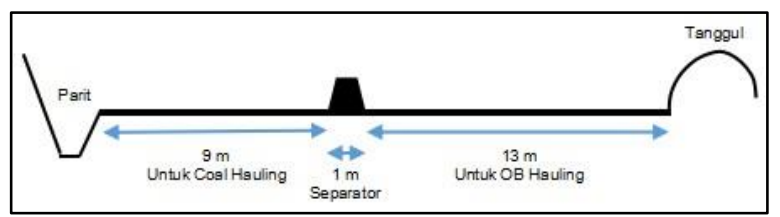

Gambar 3.9 Pembagian Jalan

\section{KESIMPULAN}

Berdasarkan pembahasan yang telah dilakukan, maka dapat diambil kesimpulan:

1. Dibuat beberapa model akses untuk jalan masuk dan jalan keluar yang dapat diterapkan dari aspek teknik pertambangan, yaitu:

a. Design dua akses jalan masuk dan keluar, akses dibentuk di low wall dan high wall dimana akses highwall untuk akses OB dan akses low wall untuk akses coal dengan lebar jalan masingmasing $20 \mathrm{~m}$;

b. Membuat jalan yang sudah ada saat ini dengan lebar $25 \mathrm{~m}$, dengan membagi jalan menjadi 2 (dua) bagian dengan separator, yaitu $9 \mathrm{~m}$ untuk alat angkut batubara dan $13 \mathrm{~m}$ untuk alat angkut material OB;

2. Tingkat efektivitas keterambilan cadangan apabila ditinjau dari aspek konservasi mineral dan batubara adalah:

a. Design dua akses jalan masuk dan keluar, yang dibentuk di low wall dan high wall, maka cadangan terambil akan berkurang menjadi 8.841 .657 ton dari total 12.984.664 ton.

b. Membuat jalan yang sudah ada saat ini dengan lebar $25 \mathrm{~m}$, dengan membagi jalan menjadi 2 (dua) bagian dengan separator, maka cadangan terambil seluruhnya sebanyak 12.984.664 ton.

\section{DAFTAR PUSTAKA}

Anonim. 2018, Keputusan Menteri Energi dan Sumber Daya Mineral Nomor 1827 K/30/MEM/2018 tentang Pedoman Pelaksanaan Kaidah Teknik Pertambangan Yang Baik, Jakarta.

Badan Standarisasi Nasional, SNI 5015;2019, Pedoman Pelaporan Hasil Eksplorasi, Sumber Daya, dan Cadangan Batubara, Jakarta.

Anonim, 2020, Undang-undang Republik Indonesia Nomor 3 Tahun 2020 tentang Perubahan Atas Undang- Undang Republik Indonesia Nomor 4 Tahun 2009 tentang Pertambangan Mineral dan Batubara, Jakarta.

Anonim. 2020, Dokumen Studi Kelayakan Revisi III PT XYZ, Lahat.

Anonim. 2021, Dokumen Rencana Kerja Anggaran dan Biaya Tahun 2021 PT XYZ, Lahat.

Anonim. 2021, Kajian Teknis Akses Jalan PT $X Y Z$, Lahat. 